\title{
PENGEMBANGAN MEDIA BIG BOOK UNTUK PEMBELAJARAN BAHASA INDONESIA DI KELAS 3 SEKOLAH DASAR
}

\author{
${ }^{1}$ Amelia Anggraini, ${ }^{2}$ Otang Kurniaman, ${ }^{3}$ Munjiatun \\ ${ }_{1,2,3}$ Universitas Riau, Indonesia. \\ Email: ${ }^{1}$ amelia.anggraini2170@ @student.unri.ac.id, ${ }^{2}$ otang.kurniaman@lecturer.unri.ac.id, \\ ${ }^{3}$ munjiatun.@lecturer.unri.ac.id
}

\begin{abstract}
This study aims to develop big book media for learning Indonesian in grade 3 elementary school and to determine the feasibility of big book learning media. This research uses research and development $(R \& D)$ methods using the FOUR-D (Define, Design, Develop and Disseminte) model. The data collection technique used is by using questionnaires and trials. The feasibility of big book learning media is obtained from the results of media validation and testing. Validation was carried out by material experts and learning media experts. The results of the research show that the validation of the material experts and the validation of the learning media experts are very valid. The trials used in this study were limited to 10 students and received a very good response. The results of this development research indicate that the big book media for learning Indonesian in grade 3 Elementary School is very suitable for use in learning in Elementary School.
\end{abstract}

Keywords: Media, Big Book, Indonesian Language Learning.

\begin{abstract}
ABSTRAK
Penelitian ini bertujuan untuk mengembangkan media big book untuk pembelajaran bahasa Indonesia di kelas 3 Sekolah Dasar dan dan untuk mengetahui kelayakan dari media pembelajaran big book. Penelitian ini menggunakan metode penelitian dan pengembangan atau Research and Development (R\&D) dengan menggunakan model FOUR-D (Define, Design, Developt and Disseminte). Teknik pengumpulan data yang digunakan yaitu dengan menggunakan angket dan uji coba. Kelayakan media pembelajaran big book diperoleh dari hasil validasi dan uji coba media. Validasi dilakukan oleh ahli materi dan ahli media pembelajaran. Hasil penellitian menunjukkan bahwa validasi ahli materi dan validasi ahli media pembelajaran sangat valid. Uji coba yang digunakan pada penelitian ini yaitu uji coba terbatas pada 10 orang siswa dan mendapatkan repson yang dikategorikan sangat baik. Hasil penelitian pengembangan ini menunjukkan bahwa media big book untuk pembelajaran bahasa Indonesia di kelas 3 Sekolah Dasar sangat layak digunakan dalam pembelajaran di Sekolah Dasar.
\end{abstract}

Kata Kunci: Media, Big Book, Pembelajaran Bahasa Indonesia.

\section{PENDAHULUAN}

Pembelajaran Bahasa Indonesia di Sekolah Dasar merupakan proses yang memberikan rangsangan belajar berbahasa kepada siswa dalam upaya siswa untuk mencapai kemampuan berbahasa. Pembelajaran bahasa Indonesia di Sekolah Dasar didasarkan pada 4 aspek keterampilan berbahasa, yaitu membaca, menulis, menyimak dan berbicara, Sholikhah (2017). Dari ke empat keterampilan berbahasa salah satunya adalah keterampilan membaca. Membaca adalah salah satu aspek yang paling penting dikuasai siswa Sekolah Dasar. Membaca akan meningkatkan pemahaman bacaan dan penggandaan kosakata, Syafitri (dalam Kurniaman dan Sismulyasih, 2019). Pada kegiatan membaca siswa tidak hanya dituntut untuk mampu membaca, melainkan juga harus mampu memahami makna atau informasi yang disampaikan melalui teks bacaan. Memahami makna bacaan memiliki arti bahwa mampu memahami maksud dari teks bacaan secara benar. Siswa harus mampu mengidentifikasi atau menentukan 
informasi dari teks yang telah dibaca. Dalam setiap buku tematik di Sekolah Dasar terdapat pelajaran Bahasa Indonesia. Terdapat banyak kegiatan membaca pada proses pembelajaran bahasa Indonesia di Sekolah Dasar.

Dalam proses pembelajaran, pelajaran bahasa Indonesia di Sekolah Dasar sering melaksanakan kegiatan membaca suatu teks bacaan. Dalam kegiatan membaca guru biasanya menggunakan buku siswa sebagai media untuk membaca. Di mana buku siswa tersebut berisi tulisan yang dilengkapi sedikit gambar. Kurangnya variasi media ketika kegiatan membaca akan menimbulkan dampak terhadap siswa. Hal tersebut dapat menyebabkan siswa mudah menjadi merasa bosan, berkhayal ketika belajar, tidak aktif, dan tidak bersemangat ketika membaca suatu teks bacaan. Serta akan menjadi sesuatu hal yang sulit bahkan menakutkan bagi siswa yang belum lancar membaca. Berdasarkan hasil wawancara dengan guru kelas III SD Negeri 164 Pekanbaru, masih terdapat siswa yang mengalami kesulitan membaca, karena setiap siswa memilki keterampilan membaca yang berbeda-beda. Pada kegiatan membaca. jika tidak terdapat media, maka siswa akan berkhayal ketika membaca, karena tidak tahu apa yang dimaksud dengan teks bacaan yang dibacanya. Hal tersebut akan berdampak pada penguasaan materi yang dipelajari siswa. Akan terdapat siswa yang tidak dapat memahami materi dikarenakan tidak tertarik untuk membaca, mudah bosan, dan tidak bersemangat ketika belajar.

Untuk terciptanya pembelajaran yang efektif dibutuhkan media pembelajaran. Menurut Untari, Budiman dan Kusumaningrum (2018) media pembelajaran merupakan perantara yang digunakan guru dalam menyampaikan materi pembelajaran supaya lebih mudah diserap oleh siswa. Penggunaan media pembelajaran sangat penting sekali digunakan pada saat pembelajaran, karena akan membawa manfaat yang positif baik bagi siswa ataupun guru. Pada usia siswa Sekolah Dasar, siswa akan lebih memahami materi jika terdapat sesuatu hal yang menarik perhatian mereka ketika belajar. Karena media memiliki pengaruh yang besar pada proses pembelajaran. Media yang menarik akan membuat siswa lebih bersemangat ketika belajar serta menciptakan suasana kelas yang menyenangkan dan aktif.

Terdapat berbagai jenis media yang dapat digunakan guru dalam pembelajaran, salah satunya media big book. Big book merupakan buku gambar besar yang berisi cerita singkat disertai gambar, Dayu (2017). Dengan adanya gambar yang menarik dan dilengkapi cerita singkat yang terdapat dalam big book, akan membuat siswa bersemangat ketika belajar. Selain itu, big book akan membuat siswa lebih fokus terhadap bahan bacaan dan guru. Membaca teks bacaan yang dilengkapi gambar akan memudahkan siswa untuk memperoleh informasi. Karena gambar dalam cerita memiliki dua fungsi yaitu memberikan pemahaman yang menyeluruh dan memberikan ransangan imajinasi, Adipta, Maryaeni \& Hasanah, (2016). Melalui media big book siswa akan mudah mengingat kembali informasi yang telah diperolehnya. Serta big book akan membuat perasaan ingin tahu dan antusias untuk memahami materi atau menemukan informasi dari teks bacaan. Media big book akan membuat siswa tertarik untuk membaca teks bacaan atau materi pembelajaran. Oleh karena itu, dengan adanya media big book diharapkan dapat memberikan variasi media yang digunakan pada kegiatan membaca, menambah semangat belajar siswa dan bisa menarik perhatian siswa dalam pembelajaran Bahasa Indonesia dalam kegiatan membaca suatu teks bacaan. Serta siswa dapat mudah memahami dan mengingat informasi yang disampaikan melalui kegiatan membaca. 


\section{METODE PENELITIAN}

Jenis penelitian yang digunakan dalam pengembangan media pembelajaran big book ini, menggunakan Research and Developmen $(R \& D)$ dengan menggunakan model pengembangan Four-D yang memiliki 4 tahap utama yaitu Define (pendefinisian), Design (perancangan), Develop (pengembangan), dan Disseminate (penyebaran). Metode $(R \& D)$ adalah metode penelitian yang digunakan untuk menghasilkan produk tertentu dan menguji keefektifan produk tersebut, (Sugiyono, 2018:297). Model pengembangan Four-D ini dipilih karena bertujuan untuk menghasilkan produk berupa media Big book. Produk yang dikembangkan kemudian diuji kelayakannya dengan uji validitas dan uji coba produk untuk mengetahui sejauh mana kelayakan dari media big book.

Jenis data dalam penelitian ini yaitu data kuantitatif dan sumber data diperoleh dari validator dan siswa. Data dalam penelitian ini adalah data kuantitatif berupa angka yang diperoleh dari validasi produk dan uji coba respon siswa. Sedangkan sumber data diperoleh dari data hasil penelitian dari validator ahli media pembelajaran dan ahli materi untuk melihat kelayakan media berupa angket validasi produk dan data uji coba produk untuk melihat respon siswa menggunakan angket respon siswa.

Dalam penelitian dan pengembangan ini menggunakan angket dalam pengumpulan data. Dalam melakukan analisis data dalam penelitian ini menggunakan skala Likert, Alim, Syahrilfuddin dan Witri (2009:44) menjelaskan bahwa dalam skala ini hanya menggunakan item yang secara pasti baik dan secara pasti buruk. Skala Likert yang digunakan yaitu menggunakan skor 1-4. Berikut ketentuan pemberian skor sesuai dengan skala likert 1-4.

\section{Tabel 1. Ketentuan Pemberian Skor}

\begin{tabular}{cc}
\hline Skor Penilaian & Kategori \\
\hline 4 & Sangat Setuju (SS) \\
\hline 3 & Setuju (S) \\
\hline 2 & Tidak Setuju (TS) \\
\hline 1 & Sangat Tidak setuju (STS) \\
\hline
\end{tabular}

Sumber: (Sugiyono, 2018: 94)

Setelah memperoleh penilaian, maka selanjutnya yaitu menentukan persentase skor penilaian yang diperoleh dengan menggunakan rumus sebagai berikut:

Persentase $=\frac{\text { skor yang diperoleh }}{\text { skor maksimum }} \times 100 \%$

Adapun kriteria dalam mengambil keputusan validasi media maupun respon peserta didik yang telah diperoleh selanjutnya dikonfersi menjadi data kualitatif dengan mengambil keputusan berdasarkan ketentuan sebagai berikut:

Tabel 2. Kriteria Validasi Big Book.

\begin{tabular}{cc}
\hline Skor Persentase $(\%)$ & Kategori \\
\hline $82 \%-100 \%$ & Sangat Valid \\
\hline $63 \%-81 \%$ & Valid \\
\hline $44 \%-62 \%$ & Kurang Valid \\
\hline $25 \%-43 \%$ & Sangat Kurang Valid \\
\hline
\end{tabular}


Tabel 3. Kriteria Respon Siswa

\begin{tabular}{cc}
\hline Skor Persentase $(\%)$ & Kategori \\
\hline $82 \%-100 \%$ & Sangat Baik \\
\hline $63 \%-81 \%$ & Baik \\
\hline $44 \%-62 \%$ & Kurang Baik \\
\hline $25 \%-43 \%$ & Sangat Kurang Baik \\
\hline
\end{tabular}

\section{HASIL DAN PEMBAHASAN}

Hasil

Media big book dikembangkan dengan menggunakan model pengembangan FOUR-D yang memiliki 4 tahap utama yaitu Define (pendefinisian), Design (perancangan), Develop (pengembangan), dan Disseminate (penyebaran). Berikut hasil penelitian pengembangan media pembelajaran big book untuk pembelajaran Bahasa Indonesia di kelas 3 Sekolah Dasar.

\section{a. Tahap Define (pendefinisian)}

Tahap pendefinisian yang dilakukan yaitu terdiri dari 3 langkah, yaitu sebagai berikut:

1) Analisis awal

Analisis awal peneliti dilakukan pada bulan November 2020 dilaksanakan di SDN 164 Pekanbaru. Pada analisis awal ditemukan bahwa dalam pembelajaran bahasa Indonesia pada kegiatan membaca hanya menggunakan buku tematik sebagai media pembelajaran untuk membaca. Pada kegiatan membaca diketahui juga bahwa media pembelajaran yang digunakan kurang bervariasi. Serta diketahui juga bahwa siswa kurang memahami isi bacaan ketika membaca, dikarenakan membaca teks yang terlalu panjang yang membuat mereka bosan dan tidak bersemangat.

2) Analisis Peserta Didik

Analisis peserta didik dilakukan peneliti bersamaan dengan analisis awal dengan cara mencari tahu karakteristik peserta didik. Dapat diketahui bahwa siswa kelas III SD rata-rata berusia antara 8-9 tahun. Dalam rentang usia tersebut siswa memiliki karakteristik yang suka bermain dan menyukai hal-hal yang unik. Hal tersebut bisa dilihat pada saat jam istirahat dan pada saat proses pembelajaran. Menurut teori Piaget, anak usia 6-11 tahun termasuk ke dalam tahap operasional kongkrit. Pada proses pembelajaran siswa tersebut lebih menyukai hal-hal yang menarik perhatian mereka dan menyenangkan. Siswa akan mudah bosan jika pembelajaran bersifat kaku dan tidak menyenangkan.

3) Analisis Materi

Materi yang akan dikembangkan dalam media big book yaitu pada pelajaran Bahasa Indonesia pada KD 3.2 yang menuntut kemampuan siswa untuk dapat menggali informasi penting tentang sumber dan bentuk energi. Merujuk pada buku guru bahwa kompetensi yang ingin dicapai siswa mengetahui informasi tentang energi alternatif dengan kegiatan pembelajaran membaca. Dengan tujuan pembelajaran, siswa dapat mengidentifikasi informasi yang berkaitan dengan energi dengan benar dan mampu menemukan kosakata/istilah yang terkait dengan perubahan energi dengan tepat. Untuk dapat memperjelas informasi penting diperlukan alat atau media untuk bisa memperjelas materi yang disajikan. 


\section{b. Tahap Design (perancangan)} berikut:

Adapun tahap design (perancangan) yang dilakukan peneliti dijelaskan sebagai

1) Konsep media big book

Big book yang dikembangkan ini dibuat dengan konsep cerita yang sederhana dengan materi yang telah ditentukan. Pada media big book ini dirancang konsep cerita bersambung dengan 2 topik cerita. Untuk cerita pertama peneliti membuat cerita tentang energi alternatif, sedangkan untuk cerita yang kedua peneliti membuat cerita tentang manfaat energi angin. Bahasa yang digunakan ialah bahasa yang mudah dimengerti untuk siswa yang dibantu dengan tampilan gambar.

2) Tokoh

Dalam pembuatan media big book terdapat tokoh ibu, Rama dan Amel. Tokoh utama dalam cerita yaitu Rama dan Amel, dengan menggunakan sudut pandang ketiga.

3) Format dan ukuran big book

Format dan ukuran big book yang dipilih yaitu dengan memakai kertas ukuran A 3 Plus sebanyak 30 halaman, yang terdiri dari 2 halaman cover, 1 halaman daftar isi, 24 halaman isi, 2 halaman Kompetensi Dasar, dan 1 halaman biografi penulis.

4) Desain gambar

Desain gambar yang digunakan dalam pembuatan big book yaitu menggunakan aplikasi Photoshop. Gambar yang dibuat sesuai dengan konsep yang telah direncanakan. Gambar yang didesain adalah gambar yang sesuai untuk siswa Sekolah Dasar. Berikut ini salah satu gambar pada big book:

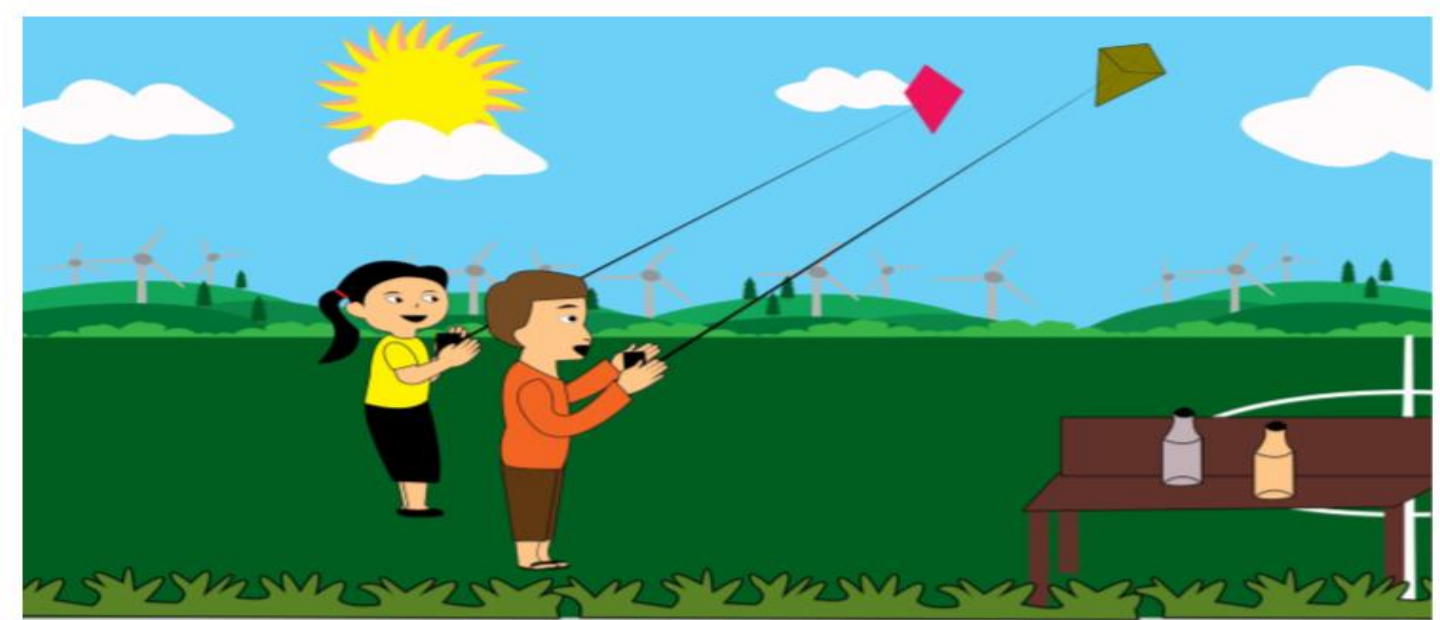

Gambar 1. Contoh Gambar Big Book

5) Teknik Pembuatan gambar

Teknik pembuatan big book menggunakan komputer melalui salah satu aplikasi desain yaitu aplikasi Photoshop. Teknik menggambar menggunakan Pen Tool dan bentuk-bentuk yang tersedia pada Rectangel Tool. 


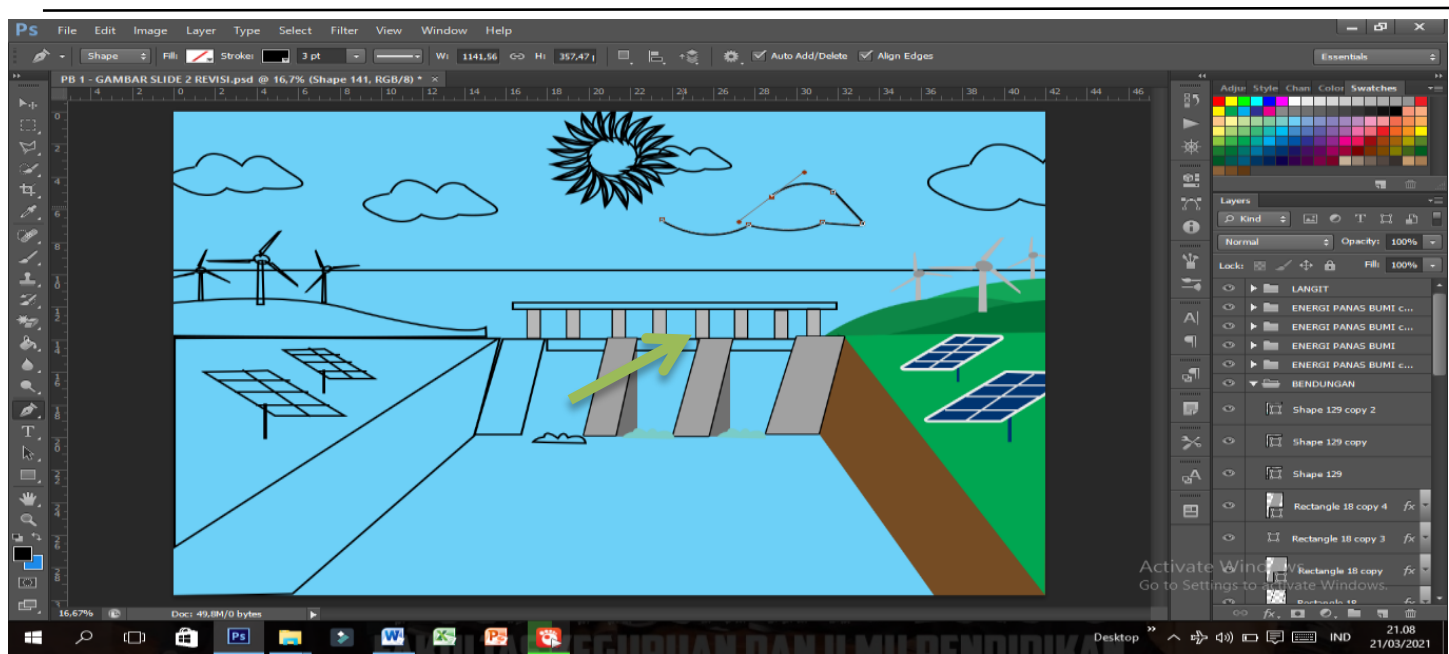

Gambar 2. Contoh Teknik Desain

6) Teknik Pewarnaan

Teknik pewarnaan menggunakan Paint Bucket Tool dan menggunakan pengaturan warna pada Set Foreground Color. Pewarnaan dalam media big book menggunakan warna yang terang dan mencolok. Warna terang dan mencolok dipilih karena warnanya akan menarik perhatian siswa untuk memperhatikan. Karena jika menggunakan warna yang soft atau lembut akan menampilkan warna gambar yang tidak mencolok dikarenakan teknik pewarnaan soft tidak cocok untuk usia siswa SD.

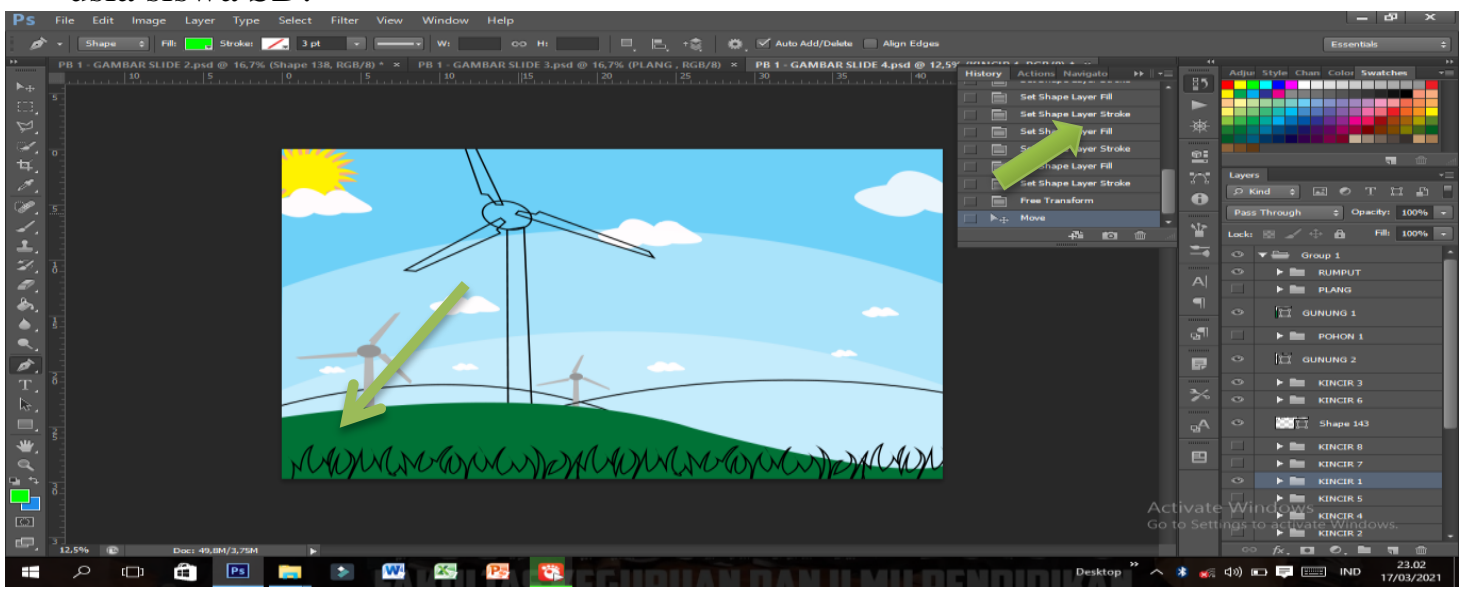

Gambar 3. Contoh Teknik Pewarnaan

7) Jenis Font

Pada pembuatan media big book ini menggunakan jenis font Comic Sans MS dan menggunakan Teks Tool untuk pembuatan teks serta ukuran 35 pt. Jenis font tersebut dipilih karena sesuai untuk usia siswa Sekolah Dasar. Pemilihan jenis font Comic Sans $M S$ ini bertujuan supaya siswa-siswi mudah ketika membaca tulisannya.

\section{c. Tahap Develop (pengembangan)}

Pada tahap pengembangan, peneliti melakukan 3 langkah dalam kegiatan ini yaitu penilaian atau validasi ahli yang terdiri dari validasi ahli media pembelajaran dan ahli materi serta peneliti melakukan uji coba terbatas. Adapun penjelasan dari 3 langkah untuk tahap Develop sebagai berikut:

1) Validasi Ahli (expert apparasial) 
Pada tahap ini dilakukan penilaian oleh para ahli yang terdiri dari ahli media pembelajaran dan ahli materi. Produk yang telah dibuat berupa media big book divalidasi dengan cara memberikan angket validasi dan memberikan big book kepada setiap ahli. Kemudian big book dinilai berdasarkan angket yang diberikan kepada setiap validator. Adapun rekapitulasi hasil validasi ahli dapat dilihat sebagai berikut:

Tabel 4. Rekapitulasi Data Hasil Validasi

\begin{tabular}{c|ccc}
\hline No. & Validator & Nilai Persentase & Kategori \\
\hline 1. & Ahli Media Pembelajaran & $92,81 \%$ & Sangat Valid \\
\hline 2. & Ahli Materi & $95,41 \%$ & Sangat Valid \\
\hline & Total & $\mathbf{1 8 8 , 2 2 \%}$ & \\
\cline { 1 - 2 } & Rata-Rata Persentase & $\mathbf{9 4 , 1 1 \%}$ & Sangat Valid \\
\hline
\end{tabular}

Berdasarkan data hasil validator di atas, persentase keseluruhan dari penilaian oleh validator pengembangan media big book untuk pembelajaran Bahasa Indonesia di kelas 3 Sekolah Dasar dengan rata-rata persentase skor sebesar 94,11\% dikategorikan sangat valid dan dapat digunakan sebagai media pembelajaran.

2) Revisi Produk

Setelah melakukan validasi media big book, terdapat beberapa perbaikan yang dilakukan pada big book. Perbaikan dilakukan berdasarkan masukan dan saran dari validator yang terdiri dari 2 ahli. Perbaikan yang dilakukan pada desain gambar, kalimat, ukuran huruf dan penggunaan tanda baca.

3) Uji coba Produk

Pada tahap ini dilakukan uji coba terbatas untuk memperoleh informasi mengenai respon siswa setelah menggunakan produk yang dikembangkan. Peneliti melakukan uji coba produk pada siswa Sekolah Dasar kelas 3 yang berjumlah 10 orang. Adapun hasil data uji coba respon siswa dapat dilihat sebagai berikut:

Tabel 5. Rekapitulasi Hasil Uji Coba Terbatas

\begin{tabular}{cccc}
\hline No. & Aspek Penilaian & $\begin{array}{c}\text { Persentase Rata- } \\
\text { Rata Aspek }\end{array}$ & Kategori \\
\hline 1. & Penggunaan Media Big Book & $94,16 \%$ & Sangat Baik \\
\hline 2. & Reaksi Siswa & $96,25 \%$ & Sangat Baik \\
\hline 3. & Tanggapan Siswa Terkait Isi Media & $98,75 \%$ & Sangat Baik \\
\hline & Rata-Rata Persentase & $\mathbf{9 6 , 3 8 \%}$ & Sangat Baik \\
\hline
\end{tabular}

Berdasarkan hasil data respon siswa terhadap media Big Book yang dikembangkan oleh peneliti diperoleh skor rata-rata persentase sebesar 96,38\% dengan kategori sangat baik. Berdasarkan hasil data uji coba tersebut secara keseluruhan big book big book yang dikembangkan mendapatkan respon yang sangat baik dari siswa yang telah menggunakan produk ini.

Selain respon siswa, peneliti juga mendapatkan respon guru mengenai media big book. Respon guru ini diperoleh dari Ibu FL yang merupakan guru kelas 3 SD. Guru tersebut memberikan respon positif terkait media yang big book yang dikembangkan. Adapun respon yang diberikan yaitu pertama, guru memberikan respon bahwa materi pelajaran bahasa Indonesia sudah terwakili oleh big book. Big book menyajikan materi 
yang sesuai dengan tujuan pembelajaran yaitu tentang energi alternatif. Kedua, media big book dapat membantu siswa dalam memahami bacaan dengan baik. Hal tersebut terjadi karena siswa bersemangat ketika membaca menggunakan media big book yang menampilkan teks bacaan yang disertai gambar yang menarik perhatian siswa. Ketiga, media big book membuat siswa lebih cepat memahami materi dibanding membaca tulisan yang panjang pada buku siswa. Karena pada big book ini materi disajikan dengan teks yang dilengkapi gambar dengan suasana yang menyenangkan.

\section{d. Tahap Dessiminate (penyebaran)}

Pada tahap ini dilakukan tahap penyebaran terbatas big book dengan melakukan Focus Group Discussion (FGD). FGD merupakan salah satu teknik mengumpulkan data kualitatif, di mana terdapat sekelompok orang berdiskusi dengan pengarahan dari seorang fasilitator mengenai suatu topik, Paramita dan Lusi (2013). Tujuan dilakukan FGD ini yaitu untuk mengumpulkan pendapat-pendapat dari peserta mengenai media big book yang telah dikembangkan peneliti, mengetahui respon mengenai media big book, kelebihan dan kekurangan big book.

Tahap penyebaran terbatas ini dihadiri peserta diskusi yaitu sebanyak 5 orang. Pada tahap FGD ini dapat diketahui bahwa pendapat dan respon peserta mengenai media big book sangat baik dan dapat disimpulkan bahwa media big book yang dikembangkan sangat sesuai untuk siswa Sekolah Dasar dan memudahkan siswa dalam memahami materi melalui kegiatan membaca, siswa bersemangat dalam kegiatan belajar, interaksi yang aktif akan terjalin dengan mudah, dapat melibatkan siswa dalam pembelajaran dan mempermudah guru menyampaikan materi, karena media big book yang dikembangkan sangat menarik karena dibuat dengan ukuran gambar dan tulisan besar yang menyajikan gambar-gambar yang dapat menarik perhatian siswa. Sedangkan saran yang diberikan oleh peserta FGD yaitu mengenai ukuran huruf pada big book yang kurang besar dan peneliti melakukan perbaikan dengan memperbesar ukuran tulisan big book yang awalnya $30 \mathrm{pt}$ diubah menjadi 35 pt.

\section{Pembahasan}

\section{Pengembangan Media Big Book Untuk Pembelajaran Bahasa Indonesia Di Kelas 3 Sekolah Dasar}

Media pembelajaran merupakan alat bantu proses belajar mengajar yaitu segala sesuatu yang dapat dipergunakan untuk merangsang pikiran, perasaan, perhatian, dan kemampuan atau keterampilan pelajar sehingga mendorong terjadinya proses belajar pada peserta didik, Rahaya, Suryaman dan Wiyorno (2019). Media menjadi sesuatu hal yang sangat berguna dalam proses pembelajaran, karena memiliki manfaat yang banyak untuk peserta didik atau pendidik. Big Book merupakan buku bacaan yang memiliki ukuran, tulisan dan gambar yang besar, USAID (dalam Buku Sumber Bagi Dosen LTPK 2014:42). Ukuran big book bisa beragam, misalnya ukuran A3, A4, A5 atau seukuran Koran. Big book adalah salah satu media yang menarik untuk digunakan pada pembelajaran bahasa Indonesia di Sekolah Dasar. Salah satunya pada kegiatan membaca, supaya siswa lebih tertarik untuk membaca sehingga menimbulkan semangat dan cepat memahami materi yang disampaikan.

Berdasarkan penjelasan hasil penelitian, pengembangan media big book dilakukan dengan menggunakan prosedur penelitian model FOUR-D. Pada model pengembangan ini terdapat 4 tahap utama yaitu, Define (Pendefinisian), Design (Perancangan), Develop (Pengembangan), dan Disseminate (Penyebaran).

Tahap pertama dalam pengembangan media big book yaitu tahap define 
(pendefinisian) terdiri dari beberapa tahapan. Pertama, tahap analisis awal untuk mengetahui permasalahan dan kebutuhan yang diperlukan untuk pengembangan big book. Kedua, analisis peserta didik dilakukan untuk mengetahui karakteristik peserta didik. sesuai dengan toeri Piaget bahwa usia 6-11 tahun termasuk ke dalam tingkat berpikir tahap operasional kongkrit, (Ibda, 2015). Siswa usia SD tersebut menyukai pembelajaran yang menyenangkan. Ketiga, analisis materi dilakukan untuk menentukan materi yang akan digunakan ke dalam pembelajaran bahasa Indonesia kelas III tema 6 (Energi dan perubahannya) subtema 3 (energi alternatif) KD 3.2 Menggali informasi tentang sumber dan bentuk energi yang disajikan dalam bentuk lisan, tulis, visual dan/atau eksplorasi lingkungan.

Tahap kedua dalam pengembangan media big book adalah Design (Perancangan). Pada tahap ini terdapat 2 tahap yaitu tahap pembuatan alur cerita big book dan tahap pembuatan desain big book. Pertama, tahap pembuatan alur cerita big book dilakukan dengan cara membuat cerita big book. Alur cerita big book dibuat setelah menentukan materi yang akan disajikan. Big book yang dikembangkan terdiri atas cover, pemetaan kompetensi Kompetensi Dasar, Indikator, tujuan pembelajaran, isi, dan biodata penulis. Kedua, tahap pembuatan desain big book dilakukan dengan menggunakan aplikasi Photoshop. Pada tahap ini dilakukan pembuatan gambar big book.

Tahap ketiga dalam pengembangan media big book adalah Develop (Pengembangan). Pada tahap ini terdapat 3 tahap yaitu tahap validasi produk, revisi, dan uji coba produk. Pertama, tahap validasi produk yaitu tahap penilaian dan pengembangan produk terhadap materi dan media pembelajaran yang dilakukan oleh 4 orang validator yang terdiri dari ahli media pembelajaran dan ahli materi. Penilaian ahli media pembelajaran memperoleh skor penilaian dengan persentase $92,81 \%$, penilaian ahli materi memperoleh skor penilaian dengan persentase 95,41\%. Kedua, tahap revisi dilakukan atas perolehan nilai kurang baik, saran dan masukan validator ahli materi dan media pembelajaran big book. Setelah dilakukan revisi maka big book dapat direview kembali hingga memperoleh kategori valid oleh validator. Ketiga, tahap ujicoba produk dilakukan untuk memperoleh respon siswa dan guru terhadap media big book. Tahap ujicoba dilakukan setelah dinilai, direvisi dan dinyatakan layak oleh validator. Tahap ujicoba produk dilakukan pada siswa kelas 3 yang berjumlah 10 orang dan memperoleh nilai respon siswa dengan persentase 96,38\% dengan kategori sangat baik.

Tahap keempat dalam pengembangan media big book adalah Disseminate (Penyebaran). Tahap penyebaran ini dilakukan dengan cara diskusi FGD (Focus Group Discusion). Tahap ini dilakukan untuk memperoleh respon atau pendapat mengenai media big book, mengetahui kekurangan big book dan saran untuk memperbaiki kekurangan pada media big book yang dikembangkan. Dari hasil diskusi dapat disimpulkan bahwa media big book sangat sesuai jika digunakan sebagai media pembelajaran dalam pelajaran bahasa Indonesia pada kegiatan membaca dan sudah sesuai untuk diajarkan kepada siswa SD terutama kelas awal. Hal tersebut juga disampaikan oleh Permatasari (2018:9) bahwa big book dapat digunakan sebagai media pembelajaran di kelas awal karena memiliki karakteristik yang sesuai dengan kebutuhan siswa.

\section{Kelayakan Media Big Book Untuk Pembelajaran Bahasa Indonesia Di Kelas 3 Sekolah Dasar.}

Kelayakan media big book dapat dilihat melalui hasil validasi produk dan uji 
coba terbatas. Validasi produk dilakukan oleh ahli materi dan media pembelajaran, sedangkan uji coba terbatas dilakukan pada 10 orang siswa kelas 3 Sekolah Dasar. Pada penilaian porduk dilakukan dengan menggunakan angket dengan skala 1-4.

Validasi ahli materi dilakukan oleh Ibu C, R dan LS. Pada tahap validasi materi memperoleh penilaian dengan persentase 95,41\% dengan kategori "sangat valid". Validasi ahli media pembelajaran dilakukan oleh Bapak Z. Pada tahap validasi media pembelajaran memperoleh penilaian dengan persentase $92,81 \%$ dengan kategori "sangat valid". Media yang telah divalidasi dan direvisi oleh ahli, selanjutnya diuji coba dengan menggunakan uji coba terbatas yang dilakukan pada siswa kelas 3 sebanyak 10 Orang. Adapun hasil uji coba tebatas yang dilakukan memperoleh persentase $96,38 \%$ dengan kategori sangat baik.

Dengan demikian, media big book untuk pembelajaran bahasa Indonesia pada siswa kelas 3 sekolah dasar sangat layak digunakan dalam proses pembelajaran. pada tahap uji coba terbatas dilaksanakan untuk menilai respon siswa. Hasil respon siswa sangat baik dalam uji coba terbatas yang menunjukkan bahwa siswa merasa sangat senang membaca ketika menggunakan media big book dan mudah memahami materi menggunakan media big book. Hal tersebut sesuai dengan pendapat Cowen (dalam Hilaliyah dan Wahid: 2020) bahwa penggunaan media visual akan membuat siswa lebih mengingat informasi dari pada hanya sekedar menggunakan media teks. Siswa usia Sekolah Dasar menyukai teks bacaan yang disertai gambar. Gambar memiliki fungsi yang sangat besar untuk siswa, karena dapat memberikan pemahaman yang lengkap kepada siswa dan memberikan ransangan imajinasi.

Media big book dibuat untuk mempermudah menyampaikan materi melalui kegiatan membaca kepada siswa. Dengan menggunakan model pengembangan FOURD (Define, Design, Develop and Dessiminate) pada pengembangan media big book ini dapat dikatakan bahwa media big book layak digunakan sebagai media untuk pembelajaran bahasa Indonesia di Sekolah Dasar.

\section{PENUTUP}

Berdasarkan hasil penelitian dan pembahasan yang telah dilakukan, maka dapat diketahui bahwa media big book berhasil dikembangkan dengan menggunakan metode penelitian (R\&D) dan model pengembangan FOUR-D (Define, Design, Develop and Dessiminate).

Kelayakan media pembelajaran big book ini diperoleh melalui hasil validasi dan uji coba terbatas. Hasil penelitian yang dilakukan menunjukkan penilaian terhadap big book dengan memperoleh nilai dari setiap validator, penilaian dari validator ahli materi dengan persentase $95,41 \%$ dan penilaian dari validator ahli media pembelajaran $92,81 \%$ dengan kategori sangat valid. Hasil uji coba produk yang dilakukan pada 10 orang siswa memperoleh nilai dengan persentase 96,38\% dengan kategori sangat baik serta respon guru mengenai media big book sangat baik. Maka dapat ditarik kesimpulan bahwa media big book yang dikembangkan sangat layak digunakan untuk pembelajaran bahasa Indonesia dikelas 3 Sekolah Dasar.

\section{DAFTAR PUSTAKA}

Adipta, H., Maryaeni \& Hasanah, M. (2016). Pemanfaatan Buku Cerita Bergambar Sebagau Sumber Bacaan Siswa SD. Jurnal Pendidikan: Teori, Penelitian dan Pengembangan, 1(5), 989-992.

Alim, J.A, Syahrilfuddin dan Witri, G. (2009). Statistik Pendidikan. Pekanbaru: Cendikia Insani. 
Buku Sumber Bagi Dosen LTPK. 2014. Pembelajaran Literasi Kelas Awal di LTPK.

Dayu, D.P. K \& Liya, A. A. (2017). Pengaruh Penggunaan Media Big Book Writing

Terhadap Ketermapilan Menulis Bahasa Indonesia Siswa Kelas 5 SD Negeri

1 Pilangbango Madiun. Jurnal Pendidikan Dasar Islam, 9(1), 21-31.

Hilaliyah, T dan Wahid, F.I. 2020. Pengembangan Media Big Bok Berbasis Budaya

Banten Untuk Meningkatkan Literasi Membaca Sastra Siswa Kelas Awal.

Prosiding Seminar Nasional PendidikAN FKIP, 3(1), 84-96.

Ibda, F. (2015). "Perkembangan Kognitif: Teori Jean Piaget". Jurnal Intelektualita, 3(1), 27-38.

Kurniaman, O dan Sismulyasih, N. (2019). The Influence of The Big Book Media Has

The Character of Conservation in Early Reading, Jurnal ELS Journal on Interdisciplinary Studies on Humanities. 2(1), 141-147.

Permatasari, A.T. 2018. Pengembangan Media Big Book Pada Pembelajaran Bahasa Indonesia Keterampilan Membaca Pemahaman Di Kelas III SDN 2 Penambongan Kecamatan Prubalingga Kabupaten Purbalingga. Purwokerto: Institut Agama Islam Negeri.

Rahaya, I.S., Suryamana \& Yoso, W. (2019). Pengembangan Media Komik pada Mata Pelajaran Bahasa Indonesia Siswa Kelas II SDN Sidotopo Wetan V Surabaya. Jurnal Education and Development, 7(2), 268-273.

Sholikhah, A. (2017). Pegembangan Media Pop Up Book Untuk Meningkatkan Kemampuan Menulis Kreatif Pada Mata Pelajaran Bahasa Indonesia Materi Menulis Karangan Kelas V SDN Rowoharjo Tahun Ajaran 2016/2017. Simki Pedagogik, 1(8),1-8.

Sugiyono. (2018). Metode Penelitian Kuantitatif, Kualitatif dan $R \&$ D. Bandung: Alfabeta.

Untari, M. F. A., Budiman, A.M, \& Kusumaningrum, D. (2018). Pengembangan Media Quiet Book untuk Pembelajaran Tematik Keluarga Sekolah Dasar Kelas 1. Jurnal Riset dan Konseptual, 3(4), 376-384. 